\title{
Coaching the Entrepreneur: Features and Success Factors
}

\section{Reference:}

Audet, J. \& Couteret, P. (2012), Coaching the Entrepreneur: Features and Success Factors, Journal of Small Business and Enterprise Development, vol. 19, n³, pp. 515-531.

\author{
Authors: \\ Josée Audet, $\mathrm{PhD}$, Professor \\ Management Department \\ Faculty of Business Administration \\ Université Laval, QUEBEC G1K 7P4 CANADA \\ Phone: + 1418 656-5435 \\ E-mail: josee.audet@mng.ulaval.ca \\ Paul Couteret, PhD, Assistant Professor \\ IUT GEA (University Institute of Technology, Business Administration Department) \\ University of Lorraine \\ Ile du Saulcy, 57000 METZ FRANCE \\ Phone: +33 372748456 \\ E-mail: paul.couteret@univ-lorraine.fr
}




\title{
Coaching the Entrepreneur: Features and Success Factors
}

\begin{abstract}
Purpose - Entrepreneurial coaching appears to be a sufficiently customized way to help novice owner-managers develop their managerial skills. However, its usefulness remains to be verified. The purpose of this research is thus to examine the effectiveness of coaching as a support measure for young entrepreneurs and to identify the factors likely to have an impact on the success of coaching initiatives.
\end{abstract}

Methodology/approach - Given the exploratory nature of the study, a flexible and open approach was chosen in order to explore the concept of coaching in some depth. The strategy retained was the case study method, with inter-site comparisons of six (6) coaching initiatives.

Findings - The findings suggest that the success of a coaching relationship is explained by a set of factors or "winning conditions," some of which are more important than others. The most crucial one appears to be the entrepreneur's open attitude to change.

Research limitations/implications - The main limitation of this study is the small number of cases observed.

Practical implications - This research provides valuable information on coaching initiatives by means of real-life examples. It also highlights several factors likely to improve the delivery of coaching services to novice entrepreneurs. It will thus prove useful to those designing coaching programs for entrepreneurs.

Originality/value of paper - Given the lack of documentation on the subject of entrepreneurial coaching, this paper has the merit of identifying some of the elements likely to contribute to the success of coaching initiatives. In addition, its findings will fuel thinking on how to enhance the benefits of coaching for novice entrepreneurs.

Keywords - Coaching, entrepreneurial support, small business support, incubator, novice entrepreneurs 
Paper type -Research paper

\section{Coaching the Entrepreneur: Features and Success Factors}

\section{Introduction}

Coaching unquestionably has a role to play in the start-up process. Isolated, entrepreneurs risk lacking the tools and support (advice, practical aids) needed to build a successful business (Gibb, 2000). They mostly require help asking the "right" questions, i.e., developing their own representations iteratively and not just in an ad hoc fashion. In particular, they must formulate and give concrete expression to their vision (Filion, 2004) through their business ventures and resulting accomplishments by developing heuristics appropriate thereto. The coach can play the role of facilitator and catalyst. It implies a personalized approach to coaching, focusing not on the business but on the entrepreneur as an individual. Entrepreneurial coaching thus appears to be a sufficiently customized way to help novice owner-managers develop their managerial skills (Bisk, 2002; Deakins et al., 1998; Graham and O’Neill, 1997).

Although the concept of entrepreneurial coaching is an attractive one, it is nevertheless relevant to question its effectiveness. Hence the research question: What factors are likely to have an impact on the success of coaching initiatives for novice entrepreneurs? This question appears to be particularly relevant in that the literature on entrepreneurial coaching is still extremely limited, undoubtedly because the phenomenon is so new. To answer the question, an exploratory study was carried out, using a coaching program developed in the Province of Quebec, Canada, as the empirical framework. The program, launched in March 2002, is financed primarily out of public funds and has already helped approximately 20 small businesses in the Mauricie region of 
Quebec (located halfway between Montreal and Québec City).

The paper begins with a review of the relevant literature, from which the proposed conceptual framework is derived. The chosen research strategy-case studies involving inter-site comparisons - is then explained, along with the methodology used. Lastly, the paper presents and discusses the findings from the six sample case studies.

\section{Literature Review}

Basically, coaching is a development approach within which one person wishing to improve his or her skills elects to be assisted by another person (Bacon, 2003). It has been explored extensively in the fields of sport (Miller, Ogilvie and Adams, 2000), education (Strong and Baron, 2004), and psychology (Laske, 1999). It is generally defined as a support structure based on a close interpersonal relationship leading to learning and the development of potential, often within a context of change.

The concept of learning by working with someone who knows the business is not new. For example, this is how the architects, sculptors, and stonemasons who built the cathedrals of the Middle Ages learned their trades. Many trades and professions still use this formula today as a means of transferring expertise. It therefore appears logical to think coaching could be used to help young entrepreneurs not yet familiar with their craft. For the purposes of this paper, entrepreneurial coaching is defined as individual support for at entrepreneurs whose firms are at the start-up or early growth stages. Its objective is the acquisition or development of skills through learning in one or more management-related fields. The ultimate aim is for the protégé to become independent in the field concerned. 
Coaching differs from consultancy in both objectives and methods (Kilburg, 1996), even though they may intervene in identical fields. Consultancy seeks to provide managers with readymade answers to specific problems, without necessarily aiming for learning outcomes. Conversely, coaches provide no direct answers to problems, but create a context of learning that equips protégés not only to find immediate answers themselves (Katz and Miller, 1996), but also solve on their own any future problems that might arise. Entrepreneur coaches are experts in the technical field(s) concerned, but are not to be confused with "classic" consultants.

A distinction must also be made between entrepreneurial coaching and mentoring. Even though the method of learning is essentially the same (i.e., maieutic), mentoring, as opposed to coaching, does not seek to provide managers with specific skills to address specific needs. Instead, it seeks to teach them how to be entrepreneurs in a much more general sense: decision making, change management, anticipation, networking skills, etc. (Bisk, 2002). Moreover, mentoring is not a business relationship: it is voluntary, for the most part, and therefore more affective for both parties (empathy, trust, respect) than cognitive (with the expectation of formal results). Coaching, on the other hand, entails a business relationship, with coaches financially rewarded for their work. Nevertheless, as the learning processes for both support structures are similar, we will sometimes use writing on mentoring to support our positions on coaching, especially where learning processes are involved.

Having examined the object of the study, we will now move on to the problem itself, namely the identification of factors likely to influence the success of coaching initiatives with novice entrepreneurs. A brief review of the literature reveals that the scientific documentation on the subject is still embryonic. The books and papers on the subject of coaching are often 
normative and have been produced mainly by consultants to promote their own recipes, rather than by researchers taking a more objective view. As a result, the review was extended to include the academic literature on mentoring and entrepreneurial consulting, due to its similarities with the concept under study in terms of processes. For presentation purposes, we will deal separately with writing on support structures, the characteristics of coaches and protégés, and the relationship between them.

The outcome of a mentor-protégé relationship will differ depending on whether the relationship was initiated formally (i.e., imposed by the structure employing the two parties) or spontaneously (i.e., through personal affinity) (Eby and Lockwood, 2005). In the case under study here, the organization managing the coaching program is responsible for selecting the "right" coach, hence the importance of the selection process. The entrepreneur receiving the support has very little time to spend on looking for outside help, and only rarely has the knowledge required to select the right person (Alstrup, 2000). The coach must be selected on the basis of the entrepreneur's real needs, and this requires a good preliminary diagnosis of his or her problems (Graham and O'Neill, 1997). The importance of the organization's manager, who often initiates and oversees the relationship, is also significant. This person appears to play a vital role in overcoming the natural resistance of novice entrepreneurs to the idea of requesting help (Bisk, 2002). Lastly, some researchers have suggested a link between the frequency of meetings between the coach (mentor) and protégé, and the protégé's perception of the value of the support received (Smallbone, Baldock, and Bridge, 1998; Waters et al., 2002).

Writing about mentoring, Mullen (1994) pointed out that considering the protégé alone would not reveal the full scale of the learning achieved, since the characteristics of the mentor 
were equally important. In the case of entrepreneurial coaching, it would appear to be essential for coaches to place themselves on the same level as their protégés. To do this, they need two qualities in particular, namely empathy and the ability to listen (Simon and Kumar, 2001; Sullivan, 2000). In addition, if they are to be accepted they need to adjust to the specific context of the entrepreneur, in terms of culture, communication method, and learning style (Dalley and Hamilton, 2000). They must therefore be familiar with the world of small business (Gibb, 2000). Beyond culture, however, small business owner-managers appear to favor advisors whose views are more compatible with their own beliefs about their firms. To be truly effective, the coach must not be considered a "stranger," but should be able to enter into the entrepreneur's world, becoming an "insider." This involves speaking the same language as the entrepreneur and finding shared representations (Dalley and Hamilton, 2000). A coach must be able to gain the protégé's trust, so that the protégé can open up, and this means establishing credibility. The entrepreneur must acknowledge the coach's expertise and believe that expertise will be useful in solving the firm's problems. But more is also required: the coach must be able to persuade the entrepreneur to accept change, acquire new knowledge or skills, and eventually change his or her behavior, too.

Even if the person providing the support exhibits all the characteristics of the "ideal" coach, the relationship will only be productive if the person receiving support is receptive to coaching. Generally speaking, small business owner-managers have a negative perception of professional advisors. There are many reasons for this. They may, for example, believe that the advice given by the consultants is not practical enough or not tailored to their situation, that the consultants charge too much for the results they achieve, or do not understand small business 
(Curran, Jarvis, Blackburn, and Black, 1993; Devins, 1999; Zinger, Blanco, Zanibbi, and Mount, 1996). Many venture creators will refuse all outside help on the basis that they prefer to remain absolutely independent (one of the principal motivations for venture creation), and also out of fear that the people around them may think they are incompetent (Curran and Blackburn, 2000).

Once these concerns have been overcome, the entrepreneur must agree to be open with the coach and, above all, be willing to change. Clearly, this involves admitting that he or she needs help, and trusting the coach's ability to provide support during the learning process. No compromise is possible; the entrepreneur must commit fully and unreservedly to the process (Clutterbuck, 1991). This means becoming actively involved in the learning process, since ultimately it is the entrepreneur who decides what to learn by making choices between the options available and placing value on the learning activities (Orth, Wilkinson, and Benfari, 1987). In reality, it would seem that entrepreneurs are usually slow to open up to the process, and often, when they decide to do so, their problems have grown to such an extent that the person providing support is no longer able to help (Dyer and Ross, 2003).

It seems to be important for coaches to place themselves on the same level as the entrepreneurs they are helping, thus promoting the type of learning best suited to them, namely learning through action (Deakins, O'Neill, and Mileham, 2000; Gibb, 1997; Gibb, 2000; Dalley and Hamilton, 2000). According to Gibb, "to learn from experience, an entrepreneur must combine his or her knowledge, skills, values, and attitudes, allowing them to interact throughout the learning process" (1997: 16). The role of the person providing support is also to help the entrepreneur to develop the ability to step back from a situation and think about the learning process (Sullivan, 2000). Spoken communication between the two players is essential, since it is 
through this that the entrepreneur will develop a new representation of the problem. It is also through communication that a relationship will develop in which the coach becomes a fellow traveler (an ally and confidant), as well as an evaluator. This is equally true for the mentoring relationship: Kalbfleisch and Davies (1993) point out that the key success factor in this type of relationship is whether or not the two parties have sufficient communication skills.

One final aspect of the coaching relationship deserves attention, namely the guidelines on which the two parties agree for the support process. It is important that they establish a kind of moral contract setting out the goals of the process, the means of achieving them, the respective roles of the parties, and a scheduled plan of action (Covin and Fisher, 1991; King and Eaton, 1999). The contract should allow the parties to manage and structure their relationship, while leaving enough flexibility to adjust as required.

\section{The Conceptual Framework for the Research}

The results of the above literature review formed the basis of the following conceptual framework.

"Take in Figure 1"

In this model, the success of the coaching initiative is judged by the perceptions of the parties, rather than by attempting to make a direct link between coaching and economic performance. In areas other than entrepreneurship (e.g., sports psychology), some authors have defined coaching success in terms of its ability to influence the protégé's learning, as well as in terms of actual performance (Feltz et al., 1999). Accordingly, three variables were retained to evaluate success in this research: 
- The extent of the change in the entrepreneur's behavior, attitude, or knowledge

- The level to which the objectives set by the parties were achieved

- The parties' level of satisfaction with the initiative

\section{Research Methodology}

Given the exploratory nature of the study, it was decided to take a flexible, open approach in order to explore the concept of coaching in some depth. The strategy retained was the case study method, using inter-site comparisons (Audet and d'Amboise, 2001), a method based largely on the work of Yin (1994) and Eisenhardt (1989).

The coaching initiatives observed for the research took place within the coaching program offered by the Mauricie region Virtual Incubator (hereinafter "the Incubator"). The services offered to the region's new firms are mostly subsidized by the government, and the firms are required to pay only $15 \%$ of the actual cost. The coaching process is structured as follows. The firm is referred to the Incubator by a local development agency that has identified a need for support. The Incubator's manager visits the firm to diagnose the problems and decide on the type of coach required. A suitable coach is then identified from the manager's vast network of contacts. The coach's first intervention usually takes place within a week of the initial referral to the Incubator. Before the first meeting, the Incubator manager talks to the coach, explaining his or her role and emphasizing that the coach is there to provide structure, not do the work in the entrepreneur's place, as a consultant would do. Once the process begins, the coach has full latitude to manage the relationship with the entrepreneur. There are only two mandatory conditions: first, the coach must spend at least one day per week with the firm; and second, the 
coach must submit a weekly report to the Incubator manager. The manager oversees the relationship through quarterly meetings with both the coach and the entrepreneur. Most coaches have a bachelor's degree or MBA; they tend to be consultants or managers, and are often retired. Although very few have prior experience of coaching, they all have extensive experience of business, and generally have experience in the field in which the entrepreneur works. All coaches are hired on a contractual basis; the Incubator's only employee is its manager.

Six coaching initiatives were selected out of the 24 sponsored so far by the Incubator. The selection was made on the basis of two criteria, namely the stage reached and the success achieved. In the first place, it was important for the initiatives to be virtually complete, so that their outcome could be assessed. Second, given that the study involved a comparison, we needed both successful and unsuccessful cases. The Incubator director was asked for his help in identifying six cases that met these criteria. He had the advantage of knowing the parties that took part in the coaching program because it was he who put them in touch with each other. He was also aware of how things had gone because coaches had updated him on the relationship each week and he had also kept in touch with the entrepreneurs throughout the coaching process.

The sample firms have been assigned fictional names: Software Inc., Kitchens Inc., Jellies Inc., Alarms Inc., Radio Inc., and Optics Inc. The general characteristics of the firms, their owner-managers, the coaches, and the coaching relationships are set out in Table I below. In the case of Software Inc., the coach was changed during the process at the request of the entrepreneur, and the results presented here are those achieved by the second relationship.

"Take in Table I" 
Before developing the data collection instruments, indicators were chosen to measure each observed variable. As the data collected was not intended to undergo statistical analysis, the goal was simply to draw the researcher's attention to the phenomenon under investigation and to make the qualitative data easier to interpret. Two interview grids were then drawn up for the data collection process, one for entrepreneurs and one for coaches. The questions contained in the grids were closed when the goal was to collect specific factual information, and both closed and open in other cases - in other words, an initial closed question was asked, followed by a second open question requiring the respondent to explain and justify the first response. Respondents were also encouraged to go beyond the questions in the guide to talk in detail about their coaching relationship; this was done to ensure that we did not miss any important aspects that were not immediately obvious. Data collection took the form of individual semi-structured interviews lasting approximately 90 minutes. Secondary data were also collected from the Incubator, including documentation and correspondence relating to the requests for assistance, the minutes of Incubator board meetings, and the Incubator's activity reports. Lastly, numerous informal meetings were held with the Incubator manager, among other things to select cases and check the findings.

Data analysis began with the writing of a case study for each case observed. The case studies included general information on the firm, the owner-manager, and the coach. The information collected was then grouped by variable and conceptual framework dimension, to facilitate inter-site comparisons. Each dimension was then examined using the available indicators and the qualitative data collected, and the cases were compared, one dimension at a time. For comparative purposes, subgroups were created based on the level of success of the 
initiative, according to whether they were successful, unsuccessful, or partly successful. After case analysis, it was deemed necessary to add the "partly successful" category in order to better represent the reality of the experiences. We then attempted to identify all the unique characteristics of the successful cases, since they were probably factors in the success of the intervention.

\section{Findings}

Findings are presented in the same order as in the literature review; we will thus begin with the results pertaining to the support structure, to move on to those related to the coach and the protégé, to finally discuss those associated with the coaching initiative. These results are summarized in Table II below.

"Take in Table II"

The principal element in the support structure is the preponderant role played by the manager, due to the fact that the coach selection process depends entirely on his judgment and business network. This type of operation is usually effective; in the six cases in our sample, all the owner-managers said they were satisfied with the manager's choice. In only one case was it necessary to change the coach, and the second choice led to one of the most successful coaching relationships in the sample. Everyone was unanimous in mentioning the importance of the "chemistry" between the two parties in the relationship. However, it is difficult to explain rationally how that "chemistry" develops and how it can be anticipated. One thing is certain: the 
Incubator manager appears to have a certain facility for matching entrepreneurs with suitable coaches. On the other hand, the weakness of the process lies in the fact that it is based on the intuition, skill, and contact network of a single person.

The Incubator manager also plays a significant information provision role. It is up to him to give the right instructions to the coaches, who usually have no prior experience of coaching. The Incubator's coaching program must also be explained to the entrepreneurs. The concept of coaching does not appear to be a familiar one, and this can cause entrepreneurs to develop unrealistic expectations of their coach. This happened in the two sample cases classified as unsuccessful; the entrepreneurs expected and actually wanted the coaches to behave as consultants and solve the problems for them. Not only does the Incubator manager set rules for the parties, but he also lays the groundwork for the coaching initiative. He played this role admirably in three of the cases observed, overcoming the entrepreneurs' natural resistance to outside help. The support the manager gives to the coaches is also extremely important. He advises them, makes them feel secure, and confirms any difficult decisions they may have to make. He was described by one of the coaches as "the coach's coach." The same person also said the manager helped him step back from the situation, since there was always a danger, in the heat of the moment, of losing sight of long-term goals. The weekly reporting requirement seems to help the coaches to review their interventions regularly, and to step back for a more objective look.

The Incubator's program requires the parties to meet at least once a week. This instruction was followed throughout the intervention in three of the cases, including the two successful ones. It therefore appears to be important not to reduce the frequency of meetings. For example, the 
number of meetings between the Alarms Inc. owner-manager and his coach gradually declined due to financial reasons. Meetings were replaced by telephone conversations and e-mails. However, the substitution had a negative impact on the coaching relationship. The coach felt it opened up a distance between himself and the entrepreneur, causing him to become detached from the firm. The Kitchens Inc. owner-manager supported this view, saying the weekly meetings, although often difficult to organize, kept him committed to the process. In the two unsuccessful cases, the meetings became sporadic after a certain time, partly because the entrepreneurs kept canceling them, and eventually died out altogether. Our observations suggest that declining frequency may be a symptom of discomfort in the relationship. Thus, when an entrepreneur begins spacing out meetings with the coach, this should be seen as an alarm signal. Contact by e-mail or telephone does not appear to be an adequate replacement for personal contact, as illustrated by the situation at Alarms Inc.

Another interesting aspect of the support structure is the speed of intervention. The entrepreneurs interviewed for the research said they were used to long delays when dealing with government services. The fact that the coaching initiative was set up within a week of their initial contact with the Incubator suggests a level of efficiency in stark contrast to the heavy bureaucracy associated with the government apparatus. This created a favorable image of the Incubator among an audience that tends to be mistrustful and cynical of government services in general.

According to the data collected from the sample entrepreneurs, the coaches all had good listening skills, and with one exception (Alarms Inc.) they all demonstrated empathy towards their protégés. Interestingly, the owner-manager of Software Inc. felt his first coach lacked 
empathy and the ability to listen, and said there was no chemistry between them. He immediately felt differently about the second coach, who listened carefully and asked a lot of questions, and this second coaching relationship turned out to be extremely productive. In the case of Alarms Inc., the relationship went into serious decline when the owner-manager began to feel the coach did not understand him. It is interesting to note that when the parties started to disagree, the first argument put forward by the entrepreneur was that the coach did not understand his viewpoint because he was not familiar with the small business context. On the other hand, as long as the coach and entrepreneur were on the same wavelength, this was never an issue. Lastly, the coaches observed all enjoyed great credibility in the eyes of the entrepreneurs. Interestingly, in the two relationships that failed, the coaches did not feel they had this credibility, even though the entrepreneurs said they had full confidence in the coach's ability to help.

All the entrepreneurs in our sample said they were generally satisfied with their coaches in this respect. It would thus appear that even when coaches possess all the desired attributes, the relationship can still end in failure, as was the case on two occasions. This suggests that these qualities are necessary for success to be achieved, but not the main reason for it.

Being receptive to coaching and especially being open to change seem to be the main conditions for coaching success. In our case studies, these conditions were not met by the two owner-managers of the firms whose coaching initiatives were unsuccessful. At Radio Inc., the entrepreneur was unreceptive from the outset; he was looking more for a consultant, who would solve his problems quickly, than for a coach. The same applied to Optics Inc., where the coaching was directed more at the employees. In terms of openness to change, there was a certain level of inconsistency in the discourse and behavior of the sample entrepreneurs. Almost all expressed a 
willingness to learn (except for the Radio Inc. owner-manager), and most said they were open to change. However, when their learning began to cast doubt on their methods and self-awareness, the entrepreneurs became extremely resistant, especially the older ones. In fact, only two of the entrepreneurs managed to change their behavior and methods significantly after the coaching initiative - these were the two "successful" cases. Once again, it was only when a relationship of trust was established between the coach and the entrepreneur that it became possible to neutralize the resistance to change.

Commitment to the relationship also appears to be a major success factor. In three of the firms where the coaching initiative was successful or partly successful (Jellies Inc., Kitchens Inc., and Software Inc.), the level of commitment on the part of the entrepreneur was high, in stark contrast to the situation at Radio Inc. and Optics Inc., where the initiative was somewhat less successful. When interviewed, the Radio Inc. owner-manager admitted he had not devoted enough time and energy to the relationship to ensure its success. He regularly canceled or postponed meetings with the coach, clearly illustrating the low value he placed on the coaching initiative.

In five of the six sample cases, the coach favored learning through action. The learning method that appeared best suited to the sample entrepreneurs was the trial-and-error approach under the coach's supervision. Learning by applying the coach's stories to the entrepreneur's own business experience or that of other entrepreneurs or managers was also successful. Finally, in two cases the coach was able to generate awareness and learning by questioning the ownermanager about the firm and about himself as a person. 
Oral communication was preponderant in most of the sample cases, either in person or on the telephone. As mentioned earlier, however, telephone communication did not appear to be as effective as a face-to-face meeting. This seems consistent with the findings of Campbell Quick and Macick-Frey (2004), who focused their coaching success approach on direct, in-depth communication.

The third and final dimension, namely the moral contract, appears to be a discriminating success factor. Indeed, it was at Radio Inc., where the coaching initiative was the least successful, that the moral contract was the least defined. Worse, the owner managers did not respect the few elements that had been agreed upon by the parties (e.g., frequency of meetings). Not only may the lack of a moral contract hinder the smooth operation of the initiative, but failure to comply may actually be harmful. For example, the coaching relationship at Alarms Inc. turned sour when the coach realized that the entrepreneur had not persevered with sales as he had promised to do and the entrepreneur realized that the initiative was not producing the anticipated results. It also seems important to shore up the moral contract by establishing short-term goals with the entrepreneurs. For example, the entrepreneurs at Software Inc. and Kitchens Inc., where the coaching initiatives were the most successful, said it was important to have "weekly goals" and "to work together to set short-term goals." One of the coaches felt it was important to emphasize the short term "so as not to frighten the protégé with the amount of work still to be done." Shortterm goals also enable the parties to measure their progress weekly and make adjustments where necessary. 


\section{Summary and Discussion of Findings}

As shown earlier, there are a number of winning conditions that must be met if a coaching initiative is to be successful. In most cases the conditions are necessary but insufficient. In other words, they were observed in both successful and unsuccessful initiatives, meaning that they did not make a difference to the level of success achieved. The protégé's commitment to the relationship and readiness to change attitudes and behavior would seem, however, to have a considerable impact on the outcome of the relationship. Entrepreneurs therefore hold the key to success themselves, as far as this support structure is concerned.

Some of the variables studied for the research deserve further attention. For example, we found that the Incubator manager played a crucial role in the coach selection process. However, the manager's responsibilities extend well beyond selection. The coaching services offered by incubators appear to have variable impacts on the entrepreneurial process, depending on each individual case, and the incubator managers appear to be major stakeholders in that process (Peters, Rice, and Sundararajan, 2004). In this case, because the Incubator manager is the first to come into contact with entrepreneurs in difficulty, the impression he gives may well have repercussions for the coaching relationship. Those repercussions may be positive if the manager is able to address the concerns and initial reticence of the entrepreneurs towards outside help. In some coaching relationships, the manager played this role admirably, while in others he was less visible. Given his credibility and excellent reputation in the business community, he could perhaps play the role of "resistance breaker" more systematically.

At the initial meeting, the Incubator manager informs the entrepreneurs of the nature and

conditions of the Incubator's coaching program. Although he said he does this for all the 
entrepreneurs coming into the program, half our sample respondents said they had not really understood the nature of the initiative at first. Coaching therefore seems to be a form of support with which the entrepreneurial community is not familiar. In the two "unsuccessful" cases in our sample, the entrepreneurs really wanted a consultant, not a coach. Perhaps if they had been asked to pay full price for the coaching service, they might have paid more attention when the Incubator manager explained what was involved. The manager's role as an information provider is therefore extremely important. He must not only give information to participants, but also ensure they have understood the rules of the game.

It may be appropriate for the Incubator manager to look at how committed the entrepreneurs are before accepting them into the program. In the two "unsuccessful" cases, the entrepreneurs told us in interview that they were not really open to the idea of changing their behavior or methods in response to the coaching. Clearly, with such an attitude the initiative was doomed from the start. In the two "partly successful" cases, the situation was more complex. The entrepreneurs said they were completely open to change, but in reality this was not so. It would therefore have been difficult for the Incubator manager to detect their lack of openness at the initial meeting. These two entrepreneurs wanted to learn, but as soon as the learning went beyond acquisition of knowledge, tools, or techniques and cast doubt on their own behavior, they began to resist. Only two entrepreneurs successfully applied their learning and, even then, they only agreed to look inwards and make changes to their behavior when they had developed a strong relationship of trust with the coach. These were, of course, the two "successful" cases. This key result confirms Peterson and Millier (2005)'s position on entrepreneurial coaching, i.e., that the protégé's position and initial commitment are crucial and must be taken into account when 
studying any coaching relationship.

\section{Conclusion}

Among the wide range of tools available to entrepreneurs, coaching is increasingly popular as a support structure. It addresses the limitations of "classic" support measures predicated on passive absorption of knowledge and ready-made formulas in a lecture-type context where entrepreneurs are told what they "must" do, without being given the opportunity to really become involved. Entrepreneurs are therefore exposed to rather standardized forms of knowledge that are unlikely in themselves to enable them to adapt to future changes. Coaching, on the other hand, encourages entrepreneurs to put their own strategic vision into action. The result is closer to learning in the sense of Piaget (1951), i.e., interaction between the subject (the entrepreneur) and the environment (the company, coach, market, etc.) and not just mere assimilation. The entrepreneur is invited to think differently rather than simply absorb advice (relevant though it may be) on the basis of past cognitive schemes. Entrepreneurial coaching thus has a maieutic role in the entrepreneurial process.

Yet, most small business owner-managers know very little about coaching, probably because its effectiveness has not yet been proven. This research has provided additional information on the coaching initiative by means of real-life examples. It also identifies some promising avenues for future research into the key success factors for entrepreneurial coaching.

The success of a coaching relationship appears to be explained by a set of factors or "winning conditions," some of which are more important than others, namely the entrepreneur's open attitude to change. It would be interesting to see if this finding is confirmed in other coaching 
support programs aimed at novice entrepreneurs or other populations.

It would also be appropriate to look in more depth at the role of the third person overseeing the coaching relationship, who is in an ideal position to influence the relationship and improve its chances of success. In the case in question, the third person was the Incubator manager, but this may not be the case in other contexts.

Obviously, this research has its limitations, including the small number of cases observed. However, given the lack of documentation on the subject of entrepreneurial coaching, it has the merit of identifying some of the elements that probably contribute to the success of coaching initiatives. In addition, its findings will fuel thinking on how to enhance the benefits of coaching for novice entrepreneurs.

\section{References}

Alstrup, L. (2000), "Coaching Continuous Improvement in Small Enterprises", Integrated Manufacturing Systems, Vol. 11 No. 3, pp. 165-170.

Audet, J. and D’Amboise, G. (2001), "The Multi-site Study: An Innovative Research Methodology", The Qualitative Report, Vol. 6 No. 2 June, consulted March $26^{\text {th }} 2007$ at: http://www.nova.edu/ssss/QR/QR6-2/audet.html.

Bacon, T. (2003), "helping People Change”, Industrial and Commercial Training, Vol. 35 No. 2 , pp.73-77.

Bisk, L. (2002), "Formal Entrepreneurial Mentoring: The Efficacy of Third Party Managed Programs", Career Development International, Vol. 7 No. 5, pp. 262-270.

Campbell Quick, J. and Macik-Frey, M. (2004), "Behind the Mask: Coaching through Deep Interpersonal Communication", Consulting Psychology Journal: Practice and Research, Vol. 56 No. 2, pp. 67-74. 
Clutterbuck, D. (1991), Everyone Needs a Mentor: Fostering Talent at Work, 2nd ed., Institute of Personnel Management, London.

Covin, T.J. and Fisher, T.V. (1991), “Consultant and Client Must Work Together”, Journal of Management Consulting, Vol. 6 No. 4, pp. 11-20.

Curran, J. and Blackburn, R.A. (2000), "Panacea or White Elephant? A Critical Examination of the Proposed New Small Business Service and Response to the DTI Consultancy Paper”, Regional Studies, Vol. 34 No. 2, pp. 181-190.

Curran, J., Jarvis, K., Blackburn, R.A., and Black, S. (1993), "Networks and Small Firms: Constructs, Methodological Strategies and Some Findings", International Small Business Journal, Vol.11 No.2, pp. 13-25..

Dalley, J. and Hamilton, B. (2000), "Knowledge, Context, and Learning in the Small Business", International Small Business Journal, Vol. 18 No. 3, pp. 51-59.

Deakins, D., O’Neill, E., and Mileham, P. (2000), “Executive Learning in Entrepreneurial Firms and the Role of External Directors", Education and Training, Vol. 42 No. 4-5, pp. 317325.

Deakins, D., Graham, L., Sullivan, R., and Whittam, G. (1998), "New Venture Support: An Analysis of Mentoring Support for New and Early Stage Entrepreneurs", Journal of Small Business and Enterprise Development, Vol. 5 No. 2, pp. 151-161.

Devins, D. (1999), "Supporting Established Micro Businesses: Policy Issues Emerging from an Evaluation”, International Small Business Journal, Vol. 18, pp. 86-96.

Dyer, L. and Ross, C. (2003), “Advising the Small Business Client”, paper presented at the 24th Canadian Council for Small Business \& Entrepreneurship Conference (CCSBE), Victoria, November.

Eby, L.T. and Lockwood, A. (2005), “Protégés' and Mentors' Reactions to Participating in Formal Mentoring Programs: A Qualitative Investigation”, Journal of Vocational Behavior, Vol. 67 No. 3, pp. 441-458.

Eisenhardt, K.M. (1989), "Building Theories from Case Study Research", Academy of Management Review, Vol. 14 No. 4, pp. 532-550. 
Feltz, D.L., Chase, M.A., Moritz, S.E., and Sullivan, P.J. (1999), “A Conceptual Model of Coaching Efficacy: Preliminary Investigation and Instrument Development”, Journal of Educational Psychology, Vol. 91 No. 4, pp. 765-776.

Filion, L.J. (2004), "Operators and Visionaries: Differences in the Entrepreneurial and Managerial Systems of Two Types of Entrepreneurs", International Journal of Entrepreneurship and Small Business, Vol. 1 No. 1/2, pp. 35-55.

Gibb, A. (1997), “Small Firms’ Training and Competitiveness: Building upon the Small Business as a Learning Organisation", International Small Business Journal, Vol. 15 No. 3, pp. 13-29.

Gibb, A. (2000), "SME Policy, Academic Research, and the Growth of Ignorance, Mythical Concepts, Myths, Assumptions, Rituals, and Confusions”, International Small Business Journal, Vol. 18 No. 3, pp. 13-34.

Graham, L. and O’Neil, E. (1997), “Sherpa or Shepherd: The Adviser Relationship in Small Firms-Mentor and/or Consultant?", paper presented at the 20th ISBA National Conference, Belfast, November.

Kalbfleisch P. et A.B. Davies (1993). "An Interpersonal Model for Participation in Mentoring Relationships", Western Journal of Communication, 57(4): 339-415.

Katz, J.H. and Miller, F.A. (1996), "Coaching Leaders through Culture Change”, Consulting Psychology Journal: Practice and Research, Vol. 48 No. 2, pp. 104-114.

Kilburg, R.R. (1996), "Toward a Conceptual Understanding and Definition of Executive Coaching”, Consulting Psychology Journal: Practice and Research, Vol. 48 No. 2, pp. 134-144.

King, P. and Eaton, J. (1999), "Coaching for Results”, Industrial and Commercial Training, Vol. 31 No. 4, pp. 145-148.

Laske, O.E. (1999), “An Integrated Model of Developmental Coaching”, Consulting Psychology Journal: Practice and Research, Vol. 51 No. 3, pp. 139-159.

Miller, T.W., Ogilvie, B., and Adams, J. (2000), "Sports Psychology: Issues for the Consultant", Consulting Psychology Journal: Practice and Research, Vol. 52 No. 4, pp. 269-276. 
Mullen, E.J. (1994), "Framing the Mentoring Relationship as an Information Exchange”, Human Resource Management Review, Vol. 4 No. 3, pp. 257-281.

Orth, C.D., Wilkinson, H.D., and Benfari, R.C. (1987), “The Manager's Role as Coach and Mentor", Organizational Dynamics, Vol. 15, pp. 66-74.

Peters, L., Rice, M., and Sundararajan, M. (2004), “The Role of Incubators in the Entrepreneurial Process", Journal of Technology Transfer, Vol. 29 No. 1, pp. 83-91.

Peterson, D.B. and Millier, J. (2005), “The Alchemy of Coaching”, Consulting Psychology Journal: Practice and Research, Vol. 57 No. 1, pp. 14-41.

Piaget, J. (1951), Psychology of Intelligence, Routledge and Kegan Paul, London.

Simon, A. and Kumar, V. (2001), “Clients' Views on Strategic Capabilities which Lead to Management Consulting Success”, Management Decision, Vol. 39 No. 5, pp. 362-372.

Smallbone, D., Baldock, R., and Bridge, M. (1998), "Targeted Support for New and Young Businesses: The Case of North Yorkshire TEC's 'Backing Winners' Programme”, Journal of Small Business and Enterprise Development, Vol. 5 No. 3, pp. 199-207.

Strong, M. and Baron, W. (2004), “An Analysis of Mentoring Conversations with Beginning Teachers: Suggestions and Responses”, Teaching and Teacher Education, Vol. 20 No. 1, pp. 47-57.

Sullivan, R. (2000), "Entrepreneurial Learning and Mentoring”, International Journal of Entrepreneurial Behavior \& Research, Vol. 6 No. 3, pp. 160-175.

Waters, L., McCabe, M., Kiellerup, D., and Kiellerup, S. (2002), “The Role of Formal Mentoring on Business Success and Self-Esteem in Participants of a New Business Start-Up Program”, Journal of Business and Psychology, Vol. 17 No. 1, pp. 107-121.

Yin, R. K. (1994), Case Study Research: Design and Methods, 2nd edition, Sage Publications, Thousand Oaks.

Zinger, J., Blanco, H., Zanibbi, L., and Mount, J. (1996), “An Empirical Study of the Small Business Support Network-The Entrepreneur's Perspective”, Canadian Journal of Administrative Sciences, Vol. 13, pp. 347-357.

WORD COUNT (without references and tables): 5969 


\begin{tabular}{|c|c|c|c|}
\hline $\begin{array}{l}\text { Characteristics of } \\
\text { the Coach } \\
\text { - Listening skills/ } \\
\text { Empathy } \\
\text { - Familiarity with } \\
\text { SME context } \\
\text { - Credibility }\end{array}$ & $\begin{array}{l}\text { Characteristics of } \\
\text { the Protégé } \\
\text { - Receptive to } \\
\text { coaching } \\
\text { - Committed to the } \\
\text { relationship }\end{array}$ & $\begin{array}{l}\text { The Coach/Protégé } \\
\text { Relationship } \\
\text { - Learning through action } \\
\text { - Oral communication } \\
\text { - Moral contract }\end{array}$ & $\begin{array}{l}\text { The Support } \\
\text { Structure } \\
\text { - Role of the } \\
\text { manager } \\
\text { - Selection process } \\
\text { - Frequency of } \\
\text { meetings }\end{array}$ \\
\hline$\downarrow$ & & $\downarrow$ & \\
\hline & $\begin{array}{l}\text { Success } \\
\text { Extent of cha } \\
\text { Level of goal } \\
\text { Level of sati }\end{array}$ & $\begin{array}{l}\text { e Coaching Initiative } \\
\text { n behaviour, attitudes or knowledge } \\
\text { evement } \\
\text { ion with the coaching relationship }\end{array}$ & \\
\hline
\end{tabular}


Table I. General Characteristics of the Firms, Owner-managers, Coaches, and Coaching Relationships

\begin{tabular}{|c|c|c|c|c|c|c|}
\hline Characteristics & Software Inc. & Kitchens Inc. & Jellies Inc. & Alarms Inc. & Radio Inc. & Optics Inc. \\
\hline Date of Creation & $02 / 21 / 00$ & $05 / 12 / 00$ & $08 / 18 / 00$ & $07 / 09 / 02$ & $08 / 25 / 99$ & 06/05/01 \\
\hline $\begin{array}{l}\text { Activities of the } \\
\text { firm }\end{array}$ & $\begin{array}{l}\text { Software services in } \\
\text { human resources }\end{array}$ & Cabinet making & $\begin{array}{l}\text { Manufacturing of } \\
\text { fruit jellies }\end{array}$ & $\begin{array}{l}\text { Alarm systems for } \\
\text { boats and trailers }\end{array}$ & $\begin{array}{l}\text { GPS identification } \\
\text { and tracking }\end{array}$ & $\begin{array}{l}\text { Manufacturing of } \\
\text { ophthalmic lenses }\end{array}$ \\
\hline Size of the firm & 9 employees & 4 employees & 8 employees & 2 employees & 4 employees & 45 employees \\
\hline Age of the protégé & $29 \mathrm{yrs}$ & $24 \mathrm{yrs}$ & $45 \mathrm{yrs}$ & $30 \mathrm{yrs}$ & $50 \mathrm{yrs}$ & $40 \mathrm{yrs}$ \\
\hline $\begin{array}{l}\text { Level of schooling } \\
\text { and work } \\
\text { experience }\end{array}$ & M.Sc. Business & $\begin{array}{l}\text { Professional } \\
\text { degree in cabinet- } \\
\text { making }\end{array}$ & $\begin{array}{l}\text { No degree but has } \\
\text { management } \\
\text { experience in retail }\end{array}$ & $\begin{array}{l}\text { Electronics } \\
\text { technician }\end{array}$ & $\begin{array}{l}\text { University degree in } \\
\text { science, has been } \\
\text { manager in a large } \\
\text { firm and } \\
\text { entrepreneur }\end{array}$ & $\begin{array}{l}\text { Lawyer and } \\
\text { financial planner, } \\
\text { has previously } \\
\text { owned a firm }\end{array}$ \\
\hline Age of the coach & $40 \mathrm{yrs}$ & 44 yrs & $35 \mathrm{yrs}$ & 55 yrs & $35 \mathrm{yrs}$ & $60 \mathrm{yrs}$ \\
\hline $\begin{array}{l}\text { Problems } \\
\text { identified }\end{array}$ & $\begin{array}{l}\text { Problems in } \\
\text { accounting and } \\
\text { finance }\end{array}$ & $\begin{array}{l}\text { General } \\
\text { management } \\
\text { weaknesses }\end{array}$ & $\begin{array}{l}\text { Weaknesses in } \\
\text { management and } \\
\text { marketing }\end{array}$ & $\begin{array}{l}\text { Problem with } \\
\text { identification of } \\
\text { target market, } \\
\text { weaknesses in } \\
\text { selling techniques } \\
\end{array}$ & $\begin{array}{l}\text { Problems with } \\
\text { marketing strategy }\end{array}$ & $\begin{array}{l}\text { New methods to be } \\
\text { put in place, work } \\
\text { climate to be } \\
\text { improved }\end{array}$ \\
\hline $\begin{array}{l}\text { Level of success } \\
\text { of the coaching } \\
\text { initiative }\end{array}$ & Successful & Successful & $\begin{array}{l}\text { Partly successful, } \\
\text { some changes } \\
\text { observed but } \\
\text { entrepreneur not } \\
\text { self-reliant yet. Both } \\
\text { parties satisfied with } \\
\text { the relationship }\end{array}$ & $\begin{array}{l}\text { Partly successful, } \\
\text { main objective } \\
\text { reached, but parties } \\
\text { less satisfied with } \\
\text { the relationship } \\
\text { towards the end }\end{array}$ & $\begin{array}{l}\text { Unsuccessful, only } \\
\text { learning in terms of } \\
\text { technical skills, } \\
\text { parties not very } \\
\text { satisfied with the } \\
\text { relationship, } \\
\text { objectives not } \\
\text { reached }\end{array}$ & $\begin{array}{l}\text { Unsuccessful, no } \\
\text { learning, parties not } \\
\text { very satisfied with } \\
\text { the relationship, } \\
\text { objectives not } \\
\text { reached }\end{array}$ \\
\hline
\end{tabular}




\begin{tabular}{|c|c|c|c|c|c|c|}
\hline Dimension & Software Inc. & Kitchens Inc. & Jellies Inc. & Alarms Inc. & Radio Inc. & Optics Inc. \\
\hline $\begin{array}{l}\text { Selection } \\
\text { process }\end{array}$ & $\begin{array}{l}\text { New coach } \\
\text { required but } \\
\text { process deemed } \\
\text { flexible and fast }\end{array}$ & $\begin{array}{l}\text { Very good coach } \\
\text { selection, speed of } \\
\text { intervention valued }\end{array}$ & $\begin{array}{l}\text { Very good coach } \\
\text { selection, speed of } \\
\text { intervention valued }\end{array}$ & $\begin{array}{l}\text { Very good coach } \\
\text { selection, speed of } \\
\text { intervention } \\
\text { valued }\end{array}$ & $\begin{array}{l}\text { Good selection, } \\
\text { but the protégé } \\
\text { would have liked } \\
\text { to have more } \\
\text { options }\end{array}$ & $\begin{array}{l}\text { Very good coach } \\
\text { selection }\end{array}$ \\
\hline $\begin{array}{l}\text { Frequency of } \\
\text { meetings }\end{array}$ & $\begin{array}{l}\text { Very high, right } \\
\text { until the end }\end{array}$ & $\begin{array}{l}\text { Very high, even } \\
\text { more so at the } \\
\text { beginning of the } \\
\text { relationship. } \\
\text { Importance of } \\
\text { maintaining the same } \\
\text { frequency. }\end{array}$ & $\begin{array}{l}\text { Very high, right } \\
\text { until the end. } \\
\text { Flexible to } \\
\text { accommodate } \\
\text { needs. } \\
\\
\end{array}$ & $\begin{array}{l}\text { Very high at the } \\
\text { beginning then, } \\
\text { only via email, } \\
\text { then a break of } 2 \\
\text { months }\end{array}$ & $\begin{array}{l}\text { High at the } \\
\text { beginning, then } \\
\text { less frequent to } \\
\text { finally stop } \\
\text { (protégé canceled } \\
\text { meetings) }\end{array}$ & $\begin{array}{l}\text { Low frequency, } \\
\text { protégé worked } \\
\text { only } \\
\text { occasionally } \\
\text { with the coach }\end{array}$ \\
\hline $\begin{array}{l}\text { Role of the } \\
\text { manager }\end{array}$ & $\begin{array}{l}\text { Role important to } \\
\text { lay the groundwork } \\
\text { for the coaching } \\
\text { initiative }\end{array}$ & $\begin{array}{l}\text { Information } \\
\text { provision role } \\
\text { deficient }\end{array}$ & $\begin{array}{l}\text { Support given to } \\
\text { coach important, } \\
\text { also secures the } \\
\text { protégé }\end{array}$ & $\begin{array}{l}\text { Support given to } \\
\text { coach important } \\
\text { but not so on the } \\
\text { protégé's side }\end{array}$ & $\begin{array}{l}\text { Support given to } \\
\text { coach important, } \\
\text { also secures the } \\
\text { protégé }\end{array}$ & $\begin{array}{l}\text { Information } \\
\text { provision role } \\
\text { deficient }\end{array}$ \\
\hline $\begin{array}{l}\text { Listening skills } \\
\text { and empathy }\end{array}$ & $\begin{array}{l}\text { Shows empathy, } \\
\text { questions the } \\
\text { protégé }\end{array}$ & $\begin{array}{l}\text { Rather good } \\
\text { listening skills, } \\
\text { protégé feels not } \\
\text { well understood at } \\
\text { times due to a lack } \\
\text { of time }\end{array}$ & $\begin{array}{l}\text { Very good } \\
\text { listening skills, } \\
\text { empathic }\end{array}$ & $\begin{array}{l}\text { Not very good } \\
\text { listening skills: } \\
\text { protégé feels not } \\
\text { well understood, } \\
\text { coach puts too } \\
\text { much pressure on } \\
\text { him }\end{array}$ & Shows empathy & $\begin{array}{l}\text { Rather good } \\
\text { listening skills, } \\
\text { empathic }\end{array}$ \\
\hline $\begin{array}{l}\text { Familiarity } \\
\text { with the SME } \\
\text { context }\end{array}$ & Very familiar & Rather familiar & Very familiar & Not very familiar & Very familiar & Rather familiar \\
\hline Credibility & $\begin{array}{l}\text { Very experienced } \\
\text { person, has a lot of } \\
\text { credibility }\end{array}$ & $\begin{array}{l}\text { Experienced person, } \\
\text { has credibility. }\end{array}$ & $\begin{array}{l}\text { Has a lot of } \\
\text { credibility, had } \\
\text { acted as consultant } \\
\text { for the firm in the } \\
\text { past }\end{array}$ & Has credibility & $\begin{array}{l}\text { Has a lot of } \\
\text { credibility, but the } \\
\text { coach did not feel } \\
\text { this from his } \\
\text { protégé }\end{array}$ & $\begin{array}{l}\text { Has a lot of } \\
\text { credibility, but } \\
\text { the coach did not } \\
\text { feel this from his } \\
\text { protégé }\end{array}$ \\
\hline $\begin{array}{l}\text { Receptivity to } \\
\text { coaching }\end{array}$ & $\begin{array}{l}\text { Very open, once } \\
\text { trust between the } \\
\text { parties is } \\
\text { established }\end{array}$ & $\begin{array}{l}\text { Very open, once } \\
\text { trust between the } \\
\text { parties is established }\end{array}$ & $\begin{array}{l}\text { Very open to } \\
\text { coaching, but not } \\
\text { to change, needs to } \\
\text { repeat the same } \\
\text { mistake a few } \\
\text { times before } \\
\text { considering change }\end{array}$ & $\begin{array}{l}\text { Very open to } \\
\text { coaching and } \\
\text { learning, but less } \\
\text { to change }\end{array}$ & $\begin{array}{l}\text { Not very open: } \\
\text { willing to learn but } \\
\text { not to change }\end{array}$ & $\begin{array}{l}\text { Not very open: } \\
\text { not willing to } \\
\text { invest the time } \\
\text { required to learn }\end{array}$ \\
\hline
\end{tabular}




\begin{tabular}{|c|c|c|c|c|c|c|}
\hline $\begin{array}{l}\text { Commitment } \\
\text { to the } \\
\text { relationship }\end{array}$ & $\begin{array}{l}\text { Very committed, } \\
\text { recognizes his } \\
\text { coach's expertise } \\
\text { and opens up to } \\
\text { him }\end{array}$ & $\begin{array}{l}\text { Very committed, } \\
\text { recognizes his } \\
\text { coach's expertise } \\
\text { and opens up to him }\end{array}$ & $\begin{array}{l}\text { Very committed, } \\
\text { but unable to } \\
\text { implement the } \\
\text { changes needed }\end{array}$ & $\begin{array}{l}\text { Became les } \\
\text { committed when } \\
\text { the coach put too } \\
\text { much pressure on } \\
\text { him, trust } \\
\text { disappeared }\end{array}$ & $\begin{array}{l}\text { Not very } \\
\text { committed, } \\
\text { recognizes his } \\
\text { coach's expertise } \\
\text { but has no time to } \\
\text { invest in the } \\
\text { relationship; } \\
\text { would have } \\
\text { preferred to have } \\
\text { an employee } \\
\text { coached }\end{array}$ & $\begin{array}{l}\text { Not committed, } \\
\text { does not open up } \\
\text { to his coach }\end{array}$ \\
\hline Moral contract & $\begin{array}{l}\text { Very detailed } \\
\text { agreement with } \\
\text { short-term } \\
\text { objectives }\end{array}$ & $\begin{array}{l}\text { Rather detailed } \\
\text { action plan with } \\
\text { short term } \\
\text { objectives, but a } \\
\text { written agreement } \\
\text { would have been } \\
\text { preferred by the } \\
\text { coach }\end{array}$ & $\begin{array}{l}\text { Very detailed } \\
\text { agreement, but the } \\
\text { parties decided to } \\
\text { change the initial } \\
\text { objectives as the } \\
\text { relationship } \\
\text { evolved }\end{array}$ & $\begin{array}{l}\text { Agreement rather } \\
\text { well defined } \\
\text { except for the role } \\
\text { of the coach and } \\
\text { the timetable; trust } \\
\text { disappeared when } \\
\text { the moral contract } \\
\text { was broken }\end{array}$ & $\begin{array}{l}\text { Agreement rather } \\
\text { vague in terms of } \\
\text { objectives, roles, } \\
\text { responsibilities } \\
\text { and timetable. }\end{array}$ & $\begin{array}{l}\text { Not very detailed } \\
\text { agreement and } \\
\text { role of the coach } \\
\text { not well } \\
\text { specified }\end{array}$ \\
\hline $\begin{array}{l}\text { Oral } \\
\text { communication }\end{array}$ & $\begin{array}{l}\text { Yes, } \\
\text { predominantly } \\
\text { communication in } \\
\text { person }\end{array}$ & $\begin{array}{l}\text { Yes, predominantly } \\
\text { communication in } \\
\text { person }\end{array}$ & $\begin{array}{l}\text { Yes, largely over } \\
\text { the telephone, but } \\
\text { also in person }\end{array}$ & $\begin{array}{l}\text { Yes, mostly in } \\
\text { person at first and } \\
\text { then over the } \\
\text { telephone }\end{array}$ & $\begin{array}{l}\text { Yes, } \\
\text { predominantly } \\
\text { communication in } \\
\text { person, some } \\
\text { written reports as } \\
\text { well }\end{array}$ & $\begin{array}{l}\text { No, } \\
\text { communication } \\
\text { largely through } \\
\text { written reports }\end{array}$ \\
\hline
\end{tabular}

